Volume 1 Nomor 1 Tahun 2021, 1 - 10
MANGGALI
Jurnal Pengabdian dan Pemberdayaan Masyarakat
http://e-journal.ivet.ac.id/index.php/manggali

\title{
Pelatihan Strategi Pengembangan UMKM melalui Jaringan Pemasaran Online di Dusun Kesongo Kecamatan Tuntang Kabupaten Semarang
}

\author{
*Eko Heri Widiastuti ${ }^{1)}$, Sri Setyaningsih ${ }^{2)}$, Zusrotin $^{3)}$, Sri Sayekti ${ }^{4}$ \\ $1,2,3,4$ Universitas Ivet \\ *ekoheriwidiastuti2@gmail.com
}

DOI: $\underline{\text { https://doi.org/10.31331/manggali.v1i1.1543 }}$

\begin{tabular}{l} 
Info Articles \\
\hline Sejarah Artikel: \\
Disubmit : November 2020 \\
Direvisi : Desember 2020 \\
Disetujui : Januari 2021 \\
Keywords: \\
training, online marketing \\
\hline
\end{tabular}

\begin{abstract}
Abstrak
Kualitas SDM akan berpengaruh pada tingkat kesejahteraan suatu masyarakat atau keluarga, bila keluarga tingkat kesejahteraannya rendah, akan berakibat pada rendahnya aspek-aspek kehidupan lain. Dusun Kesongo Kecamatan Tuntang Kabupaten Semarang, mayoritas penduduknya bermata pencaaharian sebagai petani dan memiliki tingkat kesejahteraan menengah ke bawah. Keberadaan kelompok diharapkan menjadi sarana dan motivasi dalam peningkatan kesejahteraan. Permasalahan yang ditemukan, belum maksimalnya pemanfaatan teknologi (HP) sebagai sarana promosi produknya. Paling utama dalam mengatasi berbagai persoalan tersebut adalah peningkatan kualitas SDM anggota kelompok wanita tani dengan berbagai pelatihan, terutama terkait kemampuan penggunaan teknologi (HP), khususnya media sosial (medsos) sebagai sarana pengembangan usaha yang dibangun. Luaran yang hendak dicapai adalah peningkatan pemanfaatan medsos melalui HP sebagai sarana pengembangan UMKM dari kelompok wanita tani ini. Hasil pengabdian sangat bermanfaat, sebab memunculkan motivasi dalam peningkatan pengembangan usaha semakin baik, pengelolaan, sarana prasarana juga dapat dipenuhi, walau masih dalam skala kecil. Peningkatan produksi dan perluasan pemasaran secara perlahan juga dapat ditingkatkan, namun ada kendala yang dihadapi berupa sinyal yang tidak stabil.
\end{abstract}

\begin{abstract}
The quality of human resources will affect the level of welfare of a community or family, if the family's welfare level is low, it will result in low other aspects of life. Kesongo Hamlet, Tuntang District, Semarang Regency, the majority of the population works as farmers and has a middle to lower level of welfare. The existence of groups is expected to be a means and motivation in increasing welfare. The problems found were the inadequate use of technology (HP) as a means of product promotion. The most important thing in overcoming these various problems is improving the quality of human resources for members of women farmer groups with various trainings, especially related to the ability to use technology (HP), especially social media (medsos) as a means of developing the business being built. The output to be achieved is an increase in the use of social media through cellphones as a means of developing UMKM for this group of women farmers. The results of this service are very useful, because it raises motivation in increasing business development, the better, management, infrastructure can also be fulfilled, although still on a small scale. Increased production and marketing expansion can also be increased slowly, however, there are obstacles faced in the form of an unstable signal.
\end{abstract}

Keywords: training, online marketing. 


\section{PENDAHULUAN}

Kemajuan teknologi telah merubah pola-pola kegiatan masyarata seperti, perdagangan skala luas (perdagangan antar negara), pertukaran budaya, pariwisata, kepedulian terhadap lingkungan, persaingan pasar dan sebagainya merupakan gambaran kondisi masyarakat saat ini. Adanya saling ketergantungan antar kelompok telah menimbulkan berbagai bentuk kerjasama di semua lini kehidupan sekaligus juga menimbulkn berbagai persaingan dan konflik (Marwanti dan Ismi, 2012). Akibat dari perkembangan di bidang teknologi juga diiringi dengan muculnya permasalahanpermasalahan dalam masyarakat yang semakin komplek.

Era globalisasi mengharuskan adanya perubahan dalam strategi dan metode dalam hubungan kerjasama internasional/kelompok maupun dalam pola-pola kehidupannya, baik di bidang pendidikan, politik, ekonomi dan sebagainya.Menurut National Council for thw Social Studies (NCSS, 1982), dalam proses globalisasi ada berapa fenomena antara lain: 1) adanya evolusi dalam komunikasi dan transportasi global; 2) penggabungan ekonomi lokal, regional dan nasional menjadi ekonomi global; 3) meningkatnya intensitas interaksi antar masyarakat yang menciptakan budaya global sebagai paduan dari budya lokal, regional dan nasional; dan 4) meningkatnya dampak aktivitas manusia terhadap ekosistem di bumi.

Kehidupan manusia dalam era globalisasi telah terbawa pada suatu arus yang mengharuskan kita mengubah cara pandang terhadap diri kita sendiri maupun cara pandang terhadap orang lain. Mnculnya saling keterikatan dan ketergantungan hidup telah menimbulkan peningkatan pentingnya pengusaan ilmu pengetahuan dan ketrampilan professional dari warga unia yang menjadi syarat dalam memahami dimensi global (Utama dan handayani, 2013).

Ekonomi global merupakan sistem yang sangat kompleks, yang menimbulkan saling ketergantungan, bukan sekedar hubungan sebab akibat antara konsumen dan produsen, tetapi mengungkapkan sejumlah kompleksitas dengan memfokuskan pada para pelaku ekonomi, terutama yang berkaitan dengan hubungan antar pelaku ekonomi umtuk melihat posisi mereka dalam jaringan interaksi. Sistem ekonomi saat ini dengan motif ekonominya yang mengutamakan keuntungan semata, keputusan tentang apa yang akan diproduksi dan untuk siapa diproduksi yang ditentukan oleh pasar dan kekuatan politik (Susilo, 2012). 
Usaha home industri banyak dijumpai di Dusun Kesongo Kecamatan Tuntang Kabupaten Semarang, namun pemasarannya masih bersifat tradisional belum menyesuaikan dengan perkembangan teknologi. Melihat permasalahan tersebut tim pengabdian pada masyarakat membantunya agar masyarakat mampu pengaplikasian teknologi dan keahlian kewirausahaan dengan melakukan pelatihan tentang mengembangkan jaringan pemasaran terhadap hasil usaha rumah tangga (UMKM) melalui jaringan on line dengan memanfaatkan intenet atau media sosial. Permasalahan yang ditemukan adalah masyarakat di Dusun Kesongo Kecamatan Tuntang Kabupaten Semarang belum memahani secara maksimal tentang strategi dalam pengembangan usaha rumah tangga dengan penggunaan teknologi melalui jaringan pemasaran online; dan belum memahami pentingnya kearifan lokal dalam kehidupan di era teknologi globalisasi.

\section{METODE}

Metode yang digunakan dalam kegiatan pengabdian ini dilakukan melalui beberapa langkah sebagai solusi yang ditawarkan oleh tim, dan dibagi menjadi 2 (dua), yaitu persiapan dan pelaksanaan.

1. Persiapan

1) Koordinasi dengan Kelompok Wanita Tani (UMKM) di Dusun Kesongo Kecamatan Tuntang Kabupaten Semarang dan instansi terkait.

2) Diskusi atau sarasehan untuk mengetahui pengalaman usaha, kekurangan keterampilan dalam pemasaran dan managemen anggota kelompok.

2. Pelaksanaan

1) Pelatihan tentang peningkatan kualitas SDM dalam peningkatan kemampuan penggunaan media sosial (medsos) berupa HP.

2) Pelatihan tentang inovasi pengembangan usaha dengan cara online melalui medsos.

3) Pelatihan tentang pentingnya pelestarian kearifan lokal dalam mendukung pengembangan usaha.

4) Pelatihan tentang managemen atau pengelolaan usaha.

5) Pendampingan dalam memperluas jaringan pasar (konsumen) secara online. 
Pelaksanaan pengabdian ini dapat terlaksana dengan baik diperlukan adanya partisipasi dari mitra, yaitu Pemerintahan Desa Kesongo Kecamatan Tuntang Kabupaten Semarang, bahkan pihak desa memfasilitasi kegiatan secara maksimal sehingga diperoleh hasil yang maksimal pula. Dukungan dari pihak desa tersebut antara lain adalah sebagai berikut.

1. Pemberian ijin.

2. Pihak desa memberikan apresiasi terhadap tim, sebab manfaat dari kegiatan ini dapat membantu pemerintah daerah.

3. Dukungan dari TPP PKK Desa Kesongo, karena kegiatan ini sangat membantu program PKK terutama dalam peningkatan kualitas dan pengembangan usaha home industri (UMKM) yang dilakukan oleh anggota PKK.

4. Mitra yaitu kelompok wanita tani Dusun Kesongo yang telah bekerjasama dalam upaya peningkatan kualitas produknya.

\section{HASIL DAN PEMBAHASAN}

\section{Hasil}

Pengabdian ini bertujuan membantu mitra dalam mengatasi permasalahan yang dihadapi berupa pemanfaatan HP sebagai sarana pemasaran. Secara keseluruhan hasil pengabdian ini dinarasikan sebagai berikut.

1. Persiapan

Kegiatan ini meliputi koordinasi dengan mitra dan pihak terkait dari kelompok wanita tani di Dusun Kesongo sesuai jadwal yang direncanakan dengan penuh keterbukaan. Koordinasi bertujuan untuk menyamakan persepsi dengan mitra, terutama tentang berbagai permasalahan yang dihadapi khususnya tentang strategi pengembangan dam pemberdayaan potensi-potensi yang dimiliki masyarakat, sehingga kegiatan yang dilakukan tim tidak tumpang dindih dengan kegiatan yang sudah ada dan akan direncanakan oleh pihak desa.

Dalam sosialisasi dan koordinasi ini telah disepakati waktu, tempat, metoda serta bentuk kegiatan yang akan dilakukan dengan mitra. Tim pelaksan mempunyai persepsi yang sama, terutama tentang perlunya upaya peningkatan kualitas pengelolaan kelompok, sehingga usaha yang dilakukan kelompok wanita tani dapat semakin berbembang terutama dalam perluasan pasar. 
Koordinasi ini berlangsung dengan lancar, penuh keterbukaan dan penuh semangat, karena masing-masing pihak sepakat dan secara bersama-sama untuk mengatasi permasalahan yang dihadapi oleh mitra, yaitu kelompok wanita tani. Keterbukaan dari masing-masing pihak menghasilkan kesepakatan mengenai maksud, tujuan, dan upaya mengatasi permasalahan yang dihadapi menjadi fokus diskusi, kesepakatan yang dicapai bertujuan untuk kelancaran kegiatan, masingmasing pihak akan mengambil manfaat dari kegiatan pengabdian kepada masyarakat ini. Dalam kegiatan ini telah disepakati jadwal dan materi sarasehan serta pelatihan dalam peningkatan kemampuan anggota kelompok berupa penggunan teknologi melalui medsos dengan sarana HP.

Kegiatan sarasehan dilakukan sebagai langkah lanjutan yang dilakukan bersama mitra yaitu Kelompok Wanita Tani. Dalam sarasehan dapat diidentifikasi berbagai informasi mendalam dari berbagai permasalahan yang dihadapi oleh mitra, antara lain adalah keterbatasan pemasaran yang berakibat pada rendahnya produksi, kemudian cara pengelolaan yang masih seadanya (konvensional). Oleh sebab itu kualitas pengelolaan dan kualitas anggota kelompok harus lebih ditingkatkan, agar dapat meningkatkan produksi dan meluasnya jaringan pemasaran. Kendala yang dihadapi diantaranya adalah strategi perluasan pasar yang masih tradisional, belum menggunakan teknologi masa kini (media sosial). Permasalah lain yang cukup penting adalah belum adanya anggota kelompok yang mampu menjadi motivator dalam penggunaan teknologi (media sosial) dalam pengembangan usaha.

2. Pelaksanaan

Hasil pelaksanaan kegiatan dapat dipetakkan menjadi 2 (dua), yaitu peningkatan kualitas anggota kelompok dan pentingnya kelestarian kearifan lokal.

1) Pelatihan tentang peningkatan kualitas anggota kelompok dalam penggunaan teknologi pada pengembangkan usaha. Dalam pelatihan ini disampaikan berbagai materi yang dapat digunakan dlam peningkatan skills anggota pada penggunaan media sosial (medsos) atau online. Materi pelatihan meliputi hal-hal berikut.

a) Materi kewirausahaan

Ceramah tentang kewirausahaan ini bermaksud untuk menumbuhkan jiwa wirusaha pada peserta pelatihan, sehingga mampu melihat peluang usaha yang memungkinkan untuk dilakukan. Di era globalisasi tantangan yang dihadapi 
masyarakat sangat berat, sementara peluang kerja formal juga membutuhkan kompetensi dan keterampilan sesuai dengan kebutuhan, sehingga masyarakat khususnya anggota Kelompok Wanita Tani harus memiliki pemahaman bahwa anggota bisa mengembangkan usahanya sendiri tanpa tergantung pada suatu institusi/lembaga usaha. Dengan materi ini diharapkan anggota kelompok mampu mendorong ibu-ibu lain untuk bisa mandiri, kreatif, inovatif, dan berpikir ke depan serta tumbuh kepercayaan dirinya.

b) Materi tentang teknik komunikasi

Pemberian materi ini dimaksudkan agar setiap anggota kelompok mempunyai keterampilan dalam berkomunikasi. Keterampilan berkomunikasi sangat penting karena dalam setiap kegiatan berorgaisasi atau berkelompok membutuhkan teknik-teknik berkomunikasi yang baik. Misalnya: masingmasing anggota kelompok dapat menjalin komunikasi dengan baik dan tepat, sehingga tidak terjadi mis-komunikasi. Selain itu keterampilan berkomunikasi dapat membantu anggota kelompok untuk memperluas pemasaran.

c) Materi tentang pemasaran menggunakan teknologi atau on-line Pemasaran secara online diharapkan sebagai metode yang efektif dalam peningkatan penjualan dan pengembangan bisnis. Hal ini tidak mengherankan karena ada berbagai manfaat yang dapat diperoleh ketika memutuskan untuk melakukan pemasaran secara online. Manfaat tersebut adalah sebagai berikut.

(1) Mengurangi biaya; adalah alasan utama banyak pemilik bisnis yang lebih memilih melakukan pemasaran online dibandingkan pemasaran offline. Penggunaan medsos, website dan media internet lain kebanyakan tidak dikenakan biaya. Meskipun menggunakan iklan berbayar secara online, biaya yang dikeluarkan relatif lebih hemat jika dibandingkan dengan memasang iklan di televisi, radio, koran atau mencetak flyer dalam jumlah banyak. Pay per click juga merupakan cara terbaik untuk menghemat dan mengawasi biaya karena pembayaran didasarkan pada klik nyata yang didapat iklan. Berbeda dengan iklan media konvensional dengan biaya cukup mahal, tetapi nyatanya tidak mengetahui berapa orang yang benarbenar memperhatikan. 
(2) Cepat menentukan target; dengan kecanggihan teknologi pemasaran saat ini, pengusaha dapat menyasar dengan tepat calon konsumen yang memang tertarik atau membutuhkan produk. Teknologi saat ini mampu membuat calon konsumen memberikan informasi secara sukarela sehingga anggota dapat melacak yang dibutuhkan secara tepat.

2) Pelatihan pentingnya pelestarian kearifan lokal dalam pengembangan usaha

Kearifan lokal setiap daerah berbeda-beda, hal ini menandakan bahwa setiap daerah mempunya tradisinya masig-masing. Dalam upaya pengembangan usaha pada era globalisasi yang serba teknologi, kearifan lokal sangat diperlukan, sehingga masyarakat tetap menghargai tradisi yang dimiliki dengan cara berdampingan pada teknologi. Teknologi dijadikan alat untuk pelestarian kearifan lokal, sebab dengan kearifan lokal kehidupan masyarakat tetap harmonis, guyup, dan penuh dengan gotong-royong.

\section{Capaian Luaran}

1) Masyarakat di Dusun Kesongo sudah mulai memahami tentang strategi dalam pengembangan usaha rumah tangga dengan penggunaan teknologi melalui jaringan pemasaran online. Hal ini terlihat dari antusias warga atau anggota kelompok wanita tani dalam penggunaan perangkat yang dimiliki yaitu HP, sebagai sarana menawarkan produk. Hasil produksi di upload dalam status HP, sehingga secara tidak langsung menjadi sarana promosinya.

2) Masyarakat di Dusun Kesonggo mulai memahami pentingnya kearifan lokal dalam kehidupan di era globalisasi ini. Disadari bahwa kerifan lokal harus tetap ada dalam kehidupan bermasyarakat. Kearifan lokal bermanfaat bagi terjaganya pranata-pranata atau norma-norma sosial dalam kehidupan bermayarakat dan mampu sebagai filter dalam kehidupannya. Majunya ilmu pengetahuan dan teknologi saat ini masyarakat tidak dapat menghindar, namun tidak harus melupakan dan tetap perlu melestarikan terhadap budayanya sendiri

\section{Pembahasan}

Kelompok Wanita Tani yang menjadi sasaran dalam kegiatan ini berada di Dusun Kesongo Desa Kesongo Kecamatan Tuntang Kabupoaten Semarang yang dalam kehidupannya masih cenderung berpegang pada tradisi yang ada. Hal ini terlihat dari 
metode dalam memproduksi dan memasarkan hasil dengan penggunaan cara-cara tradisional dan sederhana. UMKM yang dibentuk belum maksimal dalam mengakomodasi kebutuhan anggota, sebab masing-masig anggota masih melangkah sendiri-sendiri. Melihat kondisi seperti ini perlu upaya pendampingan baik dari pemerintah (Pemda) maupun Pergururan Tinggi agar kelompok ini mempunyai kualitas, sehingga menjadi sarana anggota kelompok dalam pengembangan usaha dengan cara memperluas jangkauan pasar.

Peningkatan perluasan jangkauan pasar dan pentingnya kearifan lokal dalam suatu usaha yang menjadi sasaran kegiatan adalah peningkatan kemampuan penggunaan teknologi (HP) pada anggota kelompok sebagai sarana perluasan pasar, dengan tujuan agar anggota mempunyai kretifitas, motivasi yang tinggi serta meningkatnya produksi. Hal ini sangat penting karena di era globalisasi seperti sekarang persaingan usaha sangat berat, sebab kondisi masyarakat terutama golongan menengah ke bawah kondisinya lemah dan rapuh dalam hal pemenuhan kebutuhan pokoknya, sehingga harus dibantu untuk lebih siap dalam menghadapi persaingan dan pemanfaatan teknologi yang harus dikuasai.

Dalam pemenuhan kebutuhan masyarakat akan keterampilan berusaha, maka tim berusaha untuk mengadakan pendampingan pada kelompok wanita tani di Dusun Kesongo dalam upaya peningkatan kualitas dan kuantitas produksi. Upaya pendampingan ini meliputi pemberian materi yang dapat digunakan dalam peningkatan jiwa kewirausahaan, motivsi anggota kelompok, serta cara pemanfaatan teknologi untuk mempromosikan produknya.

Pelaksanaan kegiatan yang dilakukan oleh tim sangat diapresiasi oleh pemerintah daerah khususnya pemerintah Desa Kesongo, sebab secara tidak langsung membantu pemerintah dalam peningkatan taraf hidup dan keterampilan berwirausaha dari masyarakatnya. Salah satu bentuk apresiasi dari Desa Kesongo adalah dukungan motivasi, yaity berupa kehadiran yang diwakili oleh Tim PKK Kelurahan pada setiap kegiatan yang dilakukan tim pengabdian pada masyarakat dari Universitas Ivet.

Selama kegiatan pendampingan ada beberapa kendala yang dihadapi, antara lain praktik pembuatan status (DP) di HP yang terkendala dengan sinyal, sebab Dusun Kesongo secara geografis berada di dataran tinggi. Dalam mengatasi berbagai kendala ini, tim berusaha dengan memberi motivasi kepada anggota kelompok agar tidak 
berputus asa dan selalu bersemangat untuk mencoba dalam penggunaan sosial media demi pengembangan usahanya. Selain itu tim menyarankan agar pemasaran juga dilakukan melalui pertemuan-pertemuan PKK baik di tingkat RT, RW maupun desa. Komunikasi dan kerjasama antara anggota kelompok dengan tim pelaksanan kegitan menjadikan kendala-kendala yang dihadapi dapat diberikan solusi, selain itu tim juga menyarankan agar pihak desa mengajukan permohonan untuk pendirian shander agar sinyal di desa tersebut dapat berjalan dengan baik dan stabil.

\section{SIMPULAN}

Berdasarkan kegitan yang telah dilaksanakan oleh tim, maka dapat disimpulkan bahwa kegiatan PKM sangat bermanfaat seperti pada Kelompok Wanita Tani di Desa Kesongo, sebab kegiatan pendampingan ini membuat anggota kelompok mempunyai motivasi dalam pengembangan kegiatan yang sudah dilaksanakan. Selama ini cara memasarkan produk masih menggunakan sarana yang sederhana, sehingga hasil produksi terbatas, hal ini disebabkan karena kemampuan dalam penggunaan teknologi seperti HP sebagai sarana promosi yang terbatas, sarana dan prasaranan produksi juga terbatas.

Kegiatan pengabdian yang dimulai dari koordinasi, pelatihan dan pendampingan berjalan dengan lancar dan penuh kekeluargaan serta dalam suasana kondusif. Suasana ini sengaja diciptakan oleh tim agar peserta pelatihan dapat menerima materi dengan mudah, sehingga anggota mempunyai motivasi dan kemampuan dalam peningkatan dan pengembangan usahanya.

Pencapaian target dan luaran dari kegiatan pengabdian ini masih belum tercapai secara maksimal, untuk target peningkatan keterampilan anggota dalam penggunaan sarana HP. Kendala utama yang dihadapi dalam pelaksanaan kegiatan ini adalah kesulitan sinyal, dan kemampuan anggota kelompok dalam memanfaatkan media sosial dengan HP yang terbtas, sebab anggota sebagai ibu-ibu rumah tangga sering menghadapi kesibukan-kesibukan yang berkaitan dengan fungsi domestik seorang wanita, sehingga kadang tidak mempunyai waktu secara penih dalam penggunaan media sosial. Namun secara umum pelaksanaan kegiatan pengabdian pada masyarakat ini berjalan dengan lancar dan memiliki kegunaan serta manfaat bagi peserta. 


\section{DAFTAR PUSTAKA}

Barry, J., 2007. Environment and Social Theory. Routledge. London.

Heimstra, N.W., dan Mc.Farling, L., 1974. Environmental Psychology. California: Wadsworth.

Marwanti, Sri. Astuti \& Ismi. S., 2012. "Melalui Pengembangan Kewirausahaan Keluarga Menuju Ekonomi Kreatif di Kabupaten Karanganyar”. Jurnal Penelitian. Surakarta: Universitas Sebelas Maret Surakarta

Miller, Jr. G. T., 1982. Living in The Environment. California: Wdsworth Publishing Company.

Susilo, R.K.D., 2012. Sosiologi Lingkungan. Jakarta: Rajagrafindo Persada.

Utama, Agung \& Handayani, T. H. W., 2013. "Model Pemberdayaan Perempuan Miskin Melalui Pelatihan Kewirausahaan Berbasis Potensi Lokal di Kecamatan Wedi Kabupaten Klaten”. Jurnal Penelitian. Yogyakarta: UNY. 